\title{
Use of Air Cooled Condenser in Biomass Power Plants: A Case Study in Cuba
}

\author{
Yanán Camaraza-Medina $^{1 *}$, Andres A. Sánchez-Escalona ${ }^{2}$, Yoalbys Retirado-Mediaceja ${ }^{2}$, Osvaldo F. García-Morales ${ }^{1}$ \\ ${ }^{1}$ Technical Sciences Faculty, Universidad de Matanzas, Matanzas 44440, Cuba \\ ${ }^{2}$ Faculty of Metallurgy and Electromechanical, Universidad de Moa, Moa 83330, Cuba
}

Corresponding Author Email: yanan.camaraza@umcc.cu

https://doi.org/10.18280/ijht.380218

Received: 13 November 2019

Accepted: 14 May 2020

\section{Keywords:}

cost of life cycle, level cost, sugar industry, power plant, IRR, NPV

\begin{abstract}
A new project of investment developed in Cuba has 25 Biomass Power Plants (BPP) with potencies of 20 and $50 \mathrm{MW}$. The confirmed lack of water to be used in the condensers is an impediment for the project. The use of dry condensers may be a possible solution, however, the cost of the initial project and the reduction in useful power associated with its use is a limitation to consider. In order to define the feasibility of the use of ACC in these projects, a case study is carried out in which several selection criteria for investment alternatives are considered, with three other types of condensation technologies being evaluated with the objective of comparing costs of investment and operation, as well as the profits generated. The analyses were carried out for a horizon of 20 years, obtaining for the ACC uses, a pay off period of 7.6 and 8.4 years, for the facilities of 20 and $50 \mathrm{MW}$ respectively. With the uses of the selection criteria for investment alternatives, was obtained that for facilities of 20 and 50 MW respectively, the Return Interest Rate (IRR) is 18.2 and 23,8 percent, the Net Present Value (NPV) (with 15\% update rate) is equal to 1126.9 and 3024.0 MUSD, the cost of the life cycle is 10682.4 and 24406.1 MUSD, while, the levelized cost of electricity production is 0.062 and $0.071 \mathrm{USD} / \mathrm{kWh}$, with a costbenefit ratio of 0.1 and 0.13 . The results obtained confirm the feasibility of using ACC systems.
\end{abstract}

\section{INTRODUCTION}

At the present time, the deficit tried of water and the urgency of the use of the alternative sources of energy, have generated important efforts channeled to solve the existing deficiencies in the used technologies. The use of biomass as an energy source for generating electric power has been one of the most widely accepted alternatives in regions with agricultural and forestry potential [1].

As part of the strategy drawn up by the Cuban state in terms of energy and hydrological sustainability, in the five-year period 2020-2025, an appreciable group of investments are executed in the country, with the purpose of increasing the presence of renewable sources in the national matrix of energy. These include a total of 25 Biomass Power Plants (BPP) that will be associated with the same amount of Sugar Power Plants (SPP) currently in operation, the latter becoming a source of fuel biomass supply (bagasse and cane agricultural waste), being 20 and $50 \mathrm{MW}$ base powers used [2].

However, the current location of the SPP is an aggravating element for the start-up of the BPP, since there are no nearby water sources that are capable of covering the flow rates required by the condensation systems, (approximately 160 $\mathrm{m}^{3} / \mathrm{h}$ ). In the dry season (2019), 37 water basins in Cuba were declared as critical state, reducing the capacity of delivery to the minimal. This situation evidenced that Cuba is not exempt from the global water crisis [3].

According to the report [4], at the end of 2017, 32\% of water withdrawals for industrial purposes were destined for wet condensation systems. In order to reduce the consumption of water in power plants, the use of the so-called dry condensation is gaining ground, because as its name indicates it dispenses with the consumption of water for its operation, achieving savings rates close to $98 \%$ with regarding wet condensers $[4,5]$.

Dry cooling systems have the potential to almost eliminate the use of water in the BPP. Among the dry condensers, one of the most widespread is the so-called air-cooled condenser (ACC), being already known and used in the BPP located in countries such as the United States, Turkey, China, Malaysia, India, South Africa, Germany and Spain, although it has not yet been widely disseminated, since it barely covers $1 \%$ of current BPP, as proposed by Huang et al. $[6,7]$.

However, the ACC have achieved limited penetration in power plants, due to considerable compensation in terms of cost and performance, as they require a capital investment substantially greater than wet condensers because they incorporate larger heat exchangers, with huge fin areas and require additional support structures [8].

In general, the installation and operation costs of the ACC systems are currently 2.5 to 5 times higher than their wet equivalent, while the typical costs of level energy production for plants with ACC range from 40 to $80 \mathrm{USD} / \mathrm{MWh}$, being approximately $15 \%$ higher than the costs obtained with the use of wet cooling technology $[9,10]$.

In the existing and available literature, similar experiences are not reported in areas with operational and climatological similarities to national ones, so issuing a judgment on the feasibility of the possible use of ACC would require a case study in which they were simultaneously considered several 
condensation technologies, in order to establish initial investment cost and life cycle levels. To demonstrate the viability of the use of ACC in the projects of BPP planned in the country is the objective of the present paper.

\section{MATERIAL AND METHODS}

\subsection{Initial considerations for the evaluation of the planned biomass BPP}

According to the Sugar Investment Contractor Company [2], the project to be executed in the country consists of $25 \mathrm{BPP}$, which are detailed in Table 1 [11].

Table 1. Summary of the biomass BPP project

\begin{tabular}{|c|c|c|c|c|c|c|}
\hline SPP & Location & Province & (1) & (2) & (3) & (4) \\
\hline 30 de Noviembre & San Cristóbal & Artemisa & 50 & 19 & 1965 & 1079 \\
\hline Héctor Molina & San Nicolás & Mayabeque & 50 & 32 & 1629 & 876 \\
\hline Jesús Rabí & Calimete & Matanzas & 20 & & & \\
\hline Mario Muñoz & Los Arabos & Matanzas & 50 & 87 & 2950 & 1705 \\
\hline Quintín Banderas & Corralillo & Villa Clara & 20 & & & \\
\hline George Washington & Santo & Villa & 20 & & & \\
\hline & Domingo & Clara & & 190 & 338 & 1346 \\
\hline Héctor Rodríguez & $\begin{array}{c}\text { Sagua } \\
\text { la Grande }\end{array}$ & $\begin{array}{l}\text { Villa } \\
\text { Clara }\end{array}$ & 20 & & & \\
\hline Uruguay & Jatibonico & $\begin{array}{c}\text { Sancti } \\
\text { Spíritus }\end{array}$ & $50_{1}$ & 108 & 158 & 788 \\
\hline Ciro Redondo & Ciro & Ciego de & 50 & & & \\
\hline Ecuador & $\begin{array}{l}\text { Redondo } \\
\text { Baraguá }\end{array}$ & $\begin{array}{c}\text { Ávila } \\
\text { Ciego de } \\
\text { Ávila }\end{array}$ & $50^{1}$ & 152 & 160 & 740 \\
\hline Brasil & Esmeralda & Camagüey & 35 & & & \\
\hline Panamá & Vertientes & Camagüey & 201 & 1362 & 2217 & 1096 \\
\hline Batalla de Guásimas & Vertientes & Camagüey & 50 & & & \\
\hline Colombia & Colombia & Tunas & 20 & & & \\
\hline Majibacoa & Majibacoa & Tunas & 351 & 163 & 171 & 722 \\
\hline Antonio Guiteras & Puerto Padre & Tunas & 50 & & & \\
\hline Cristino Naranjo & Cacocum & Holguín & 35 & & & \\
\hline Urbano Noris & Urbano Noris & Holguín & 50 & 782 & 2569 & 1479 \\
\hline Fernando de Dios & Báguanos & Holguín & 20 & & & \\
\hline Julio A Mella & Julio A Mella & Santiago & 20 & 22 & 1197 & 1189 \\
\hline Grito de Yara & Rio Cauto & Granma & 20 & & & \\
\hline Enidio Días & Campechuela & Granma & 20 & 1 & 153 & 877 \\
\hline Ciudad Caracas & Lajas & Cienfuegos & 20 & & & \\
\hline Antonio Sánchez & Aguada & Cienfuegos & 201 & 125 & 1832 & 872 \\
\hline 5 de Septiembre & Rodas & Cienfuegos & 50 & & & \\
\hline
\end{tabular}

Notes: (1) Power generation of the planned BPP, in MW. (2) Energy generated with the use of biomass (year 2019), in GWh. (3) Total energy generated (year 2019), in GWh. (4) Total energy consumption (year 2019), in GWh.

The period of operation of the BPP is of 240 days/year. The first 150 days, the energetic source is covered with the bagasse produced by the SPP, while, in the remaining time cane agricultural waste (CAW) and forest biomass elements are used. Most of the range of operations is in the drought period, (November-March) reason why the hydrological variables used are referred to these adverse conditions [3].

The possibility of simultaneous work of the BPP and the SPP associated with it, or the shutdown of the latter, as well as the surrounding ambient temperature, generate four basic variants of work, which are:

Variant 1: BPP in operation and SPP out of service, typical day warm seasons.

Variant 2: BPP and SPP in operation, typical day warm seasons.

Variant 3: BPP in operation and SPP out of service, typical day cold seasons.

Variant 4: BPP and SPP in operation, typical day cold seasons.

The simulation of these four operating state variants for each individual preset power of the planned BPP (20 and 50 MW), is carried out by simulating the cycle in the iterative TkSolver manager.

Table 2. Hydrological description of the investment project

\begin{tabular}{|c|c|c|c|c|c|c|}
\hline SPP & $\begin{array}{l}\text { Water } \\
\text { basin }\end{array}$ & Province & (1) & (2) & (3) & (4) \\
\hline 30 de Noviembre & HS-2 N & Artemisa & I & +0.8 & +3.1 & 0.66 \\
\hline Héctor Molina & HS-5 & Mayabeque & II & -3.6 & -7.3 & 0.87 \\
\hline Jesús Rabí & M-V & Matanzas & III & -17.2 & -32.1 & 1.41 \\
\hline Mario Muñoz & M-III-Sur & Matanzas & III & -16.4 & -1.6 & 1.03 \\
\hline $\begin{array}{l}\text { Quintín } \\
\text { Banderas }\end{array}$ & VC-III-1d & Villa Clara & III & -18.4 & -44.1 & 1.55 \\
\hline $\begin{array}{c}\text { George } \\
\text { Washington }\end{array}$ & VC-III-1h & Villa Clara & III & -16.9 & +0.2 & 1.21 \\
\hline $\begin{array}{l}\text { Héctor } \\
\text { Rodríguez }\end{array}$ & VC-III-1i & Villa Clara & III & -20.4 & -21.3 & 1.46 \\
\hline Uruguay & SS-18 & S. Spíritus & II & -14.8 & -25.7 & 1.16 \\
\hline Ciro Redondo & CA-1-11 & $\begin{array}{l}\text { Ciego de } \\
\text { Ávila }\end{array}$ & III & -16.2 & -0.8 & 1.29 \\
\hline Ecuador & CA-1-9 & $\begin{array}{l}\text { Ciego de } \\
\text { Ávila }\end{array}$ & III & -19.3 & -12.6 & 1.39 \\
\hline Brasil & C-I-11 & Camagüey & III & -15.6 & -44.9 & 1.56 \\
\hline Panamá & C-I-4 & Camagüey & III & -15.4 & -9.7 & 1.24 \\
\hline $\begin{array}{l}\text { Batalla de } \\
\text { Guásimas }\end{array}$ & C-I-8 & Camagüey & III & -16.1 & -9.2 & 1.26 \\
\hline Colombia & C-I-14-1 & Tunas & III & -15.9 & -11.8 & 1.27 \\
\hline Majibacoa & LT-II-2 & Tunas & II & -14.9 & -60.8 & 1.36 \\
\hline Antonio Guiteras & LT-II-1 & Tunas & III & -15.1 & -24.2 & 1.46 \\
\hline Cristino Naranjo & HG-II-11 & Holguín & III & -15.8 & -32.8 & 1.48 \\
\hline Urbano Noris & HG-II-10 & Holguín & III & -16.3 & -72.8 & 1.74 \\
\hline Fernando de Dios & HG-II-11 & Holguín & II & -13.1 & -48.8 & 1.31 \\
\hline Julio A Mella & SC-II-1 & Santiago & III & -22.4 & -70.5 & 1.89 \\
\hline Grito de Yara & G-II-2A & Granma & II & -13.6 & -60.1 & 1.43 \\
\hline Enidio Días & G-II-2B & Granma & III & -17.5 & -7.4 & 1.28 \\
\hline Ciudad Caracas & CF-II & Cienfuegos & II & -13.9 & -39.3 & 1.25 \\
\hline Antonio Sánchez & CF-I & Cienfuegos & III & -17.8 & -44.5 & 1.62 \\
\hline 5 de Septiembre & CF-III & Cienfuegos & II & -13.1 & -35.1 & 1.19 \\
\hline
\end{tabular}

According to the institutional reports [3], in the dry season period, water sources are classified according to their levels with respect to sea level, having three fundamental classifications, which are:

1- Normal aquifer area.

2- Unfavorable aquifer exploitation area.

3- Critical aquifer exploitation area.

In the first, it is possible to use water rationally. In the second, the use of water is possible only if it complies with expenditure values established by the regulations in force, while in the last zone the continuous extraction of water is prohibited. This point of view, allows grouping conveniently the planned BPP into three groups, based on water availability. This classification is:

Group I- Abundant water availability for condensation Group II- Acceptable water availability

Group III- Low water availability

Table 2 provides the hydrological description of the place where the planned BPP will be sited. In the $25 \mathrm{BPP}$, one is located in a water basin with sufficient water for condensation, 
seven BPP in basins with acceptable availability of water for condensation and $17 \mathrm{BPP}$ in basins with insufficient water volume for condensation

\subsection{Comparative criteria of the selection matrix for the initial investment}

One method that allows establishing an initial comparison of costs and operating conditions between various condensation technologies is the well-known selection criteria for initial investment developed by Owen and Kröger [5], which is accepted and partially used by HOLTEC, GEA Power, SPX and other firms specialized in the primary selection of condensation technologies [13]. This method examines ten aspects through an expression developed for each case, which generates a punctual value. The sum of these values provides the matrix selection value of the option studied. The option that accumulates the highest score will be that best suits the case studied [14].

The evaluated elements and their corresponding score are:

1- Required cooling water flow (p1)....... 15 points

2- Distance to the source of water supply (p2). . . 15 points

3- Space requirement (p3). . . . . . . . . . 10 points

4- Period of life of the technology (p4). . . . . . 5 points

5 - Net power delivered $(\mathrm{p} 5) \ldots \ldots \ldots \ldots \ldots \ldots$ points

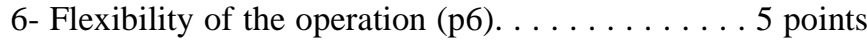

7- Cost of investment (p7) . . . . . . . . . 15 points

8- Facilities and maintenance costs (p8). . . . . . 5 points

9- Flexibility of operation and response to extreme conditions

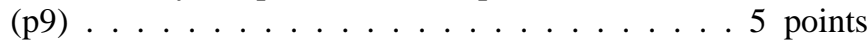
10- Level of impact on the environment (p10). . . 10 points

After the evaluation has been carried out, the scores obtained indicate which of the technologies evaluated is the most suitable for the required operation. Generally, the two variants with the highest score index are selected and a comparative case study is carried out between the two, so if there is any type of economic or environmental restriction, then make use of the one with the best opportunity cost indices [14].

The corresponding score for each element is determined separately through the help of linear relationships, as shown below:

$$
\begin{gathered}
p 1=15-0.05 \cdot m_{\text {agua }} \\
p 2=15-0.0038 \cdot L \\
p 3=10-0.006 \cdot A \\
p 4=0.1667 \cdot A_{V U} \\
p 5=25 \cdot P_{u t i l}-10 \\
p 6=-0.25 \cdot P_{\text {Back }}+6.25 \\
p 7=-0.1 \cdot M_{U S D}+16 \\
p 8=-1.66 \cdot M_{C o s t}+6.66 \\
p 9=5-0.1 \cdot P_{b a c k}-0.0125 \cdot V_{S C}-0.033 \cdot V_{E}-0.03 \cdot T_{T B S}
\end{gathered}
$$

$$
p 10=10-0.0025 \cdot T_{C O 2}
$$

Being: $m_{\text {agua }}$ is the required cooling water flow rate, in $\left(\mathrm{m}^{3} / \mathrm{h}\right) ; L$ is the distance to the source of supply to the installation, in $\mathrm{m} ; A$ is the area occupied by the condensation system, in $\mathrm{m}^{2}, A_{V U}$ is the period of useful life of the equipment given by the manufacturer, in years; $P_{u t i l}$ is the ratio of the useful power and the real power of the system; $P_{\text {Back }}$ is the steam outlet pressure of the turbine, in $\mathrm{kPa}$; MUSD is the unit cost for each MW of installed power, in MUSD; $M_{\text {cost }}$ is the value of percent of the total cost assumed for maintenance cost; $V_{S C}$ is the flow of overheated steam supplied to the turbine, in $\mathrm{kg} / \mathrm{s} ; V_{E}$ is the steam flow taken in intermediate turbine extractions, in $\mathrm{kg} / \mathrm{s} ; T_{T B S}$ is the ambient dry bulb temperature, in ${ }^{\circ} \mathrm{C} ; T_{\mathrm{CO} 2}$ is the mass of $\mathrm{CO}_{2}$ emitted by the BPP, in $\mathrm{Gg} / \mathrm{day}$.

The selection matrix is applied to four condensation technologies, two wet and two dries, in each of the four operational variants previously proposed. The technologies considered are:

Wet condensation technologies:

1- Horizontal wet condenser with one pass (HWC)

2- Wet cooling tower (WCT)

Dry condensation technologies:

1- $\quad$ Air cooled condenser (ACC)

2- $\quad$ Dry cooling tower (DCT)

Table 3 summarizes the final scores of the method for each variant and technology used. In it, it can be verified that of the dry technologies evaluated, in all cases the ACC shows a best index of selection matrix, which becomes a solid confirmation of the hypothesis proposed at the beginning of the present investigation.

Table 3. Summary of scores obtained with the application of the selection matrix method

\begin{tabular}{cccccc}
\hline Variant & Power (MW) & HWC & WCT & DCT AAC & AAC \\
\hline Warm day, & 20 & 83 & 81.6 & 73.2 & 74.2 \\
SPP out of service & 50 & 78.4 & 76.1 & 69.7 & 70.2 \\
Warm day, & 20 & 85.2 & 83.7 & 74.4 & 75.4 \\
SPP in service & 50 & 81.9 & 80.6 & 72.6 & 74.2 \\
Cold day, & 20 & 86.2 & 84.6 & 76.4 & 77.3 \\
SPP out of service & 50 & 82.7 & 80.1 & 73.1 & 73.5 \\
Cold day, & 20 & 83.1 & 81.7 & 75 & 75.8 \\
SPP in service & 50 & 80.1 & 77.8 & 71.8 & 72.2 \\
\hline
\end{tabular}

\section{MOVEMENT OF FUNDS}

\subsection{Comparative criteria of the selection matrix for the initial investment}

The movement of funds of an investment consists in determining in each one of the periods in which the horizon was divided, how many collections and how many payments are made. The analysis is done by balancing inputs and outputs. Without a fund movement, it is not possible to evaluate an investment, so it is necessary to carry out a preliminary market study, which allows including all the possibilities of offers. However, in this work, only one supplier is used, since due to the restrictions imposed on the Cuban state by the economiccommercial blockade, four suppliers consulted only receive a response from HOLTEC INTERNATIONAL. This work complies with the provisions of the current investment resolution in the country (Decree No. 327-2015). 
Table 4. Operating costs according to the Kaplan method

\begin{tabular}{ccccc}
\hline Operating cost & HWC & WCT & DCT & AAC \\
\hline Maintenance & $(0.02-0.04) \mathrm{V}_{\text {uso }}$ & $(0.03-0.07) \mathrm{V}_{\text {uso }}$ & $(0.01-0.02) \mathrm{V}_{\text {uso }}$ & $(0.015-0.03) \mathrm{V}_{\text {uso }}$ \\
Chemical water treatment & $(0.009-0.011) \mathrm{V}_{\text {uso }}$ & $(0.02-0.042) \mathrm{V}_{\text {uso }}$ & - & - \\
$\begin{array}{c}\text { Mitigation and impact by operation } \\
\text { on the environment }\end{array}$ & $(0.01-0.025) \mathrm{V}_{\text {uso }}$ & $(0.02-0.032) \mathrm{V}_{\text {uso }}$ & $(0.037-0.047) \mathrm{V}_{\text {uso }}(0.038-0.048) \mathrm{V}_{\text {uso }}$ \\
$\begin{array}{c}\text { Mitigation and impact of gas } \\
\text { emissions in the attached cycle }\end{array}$ & $(0.015-0.025) \mathrm{V}_{\text {uso }}$ & $(0.018-0.028) \mathrm{V}_{\text {uso }}$ & $(0.03-0.035) \mathrm{V}_{\text {uso }}$ & $(0.03-0.035) \mathrm{V}_{\text {uso }}$ \\
Costs of cooling water use & $(0.028-1.53)$ & $(0.028-1.53)\left(\mathrm{USD} / \mathrm{m}^{3}\right)$ & - & - \\
\hline
\end{tabular}

The movements of funds are carried out individually for the 20 and 50 MW BPP, using Kaplan's simplified methodology, which according to the work $[15,16]$, allows the approximate levels of operating costs based on the updated use value of the equipment examined. This methodology is widely accepted among specialists in the field in North America [17, 18]. The intervals recommended by Kaplan are shown in Table 4 . In Table $4, V_{u s o}$ is the use value of the equipment.

All initial equipment costs, (factory inspection, technical assistance, import duty, freight, insurance, basic engineering and inspection at final destination port), were obtained in direct communication with ENERGOIMPORT, the only authorized entity in Cuba for to import facilities destined for the energy industry. The current external financing available to this entity is of Chinese origin, with a bank interest of $5.5 \%$ and an update rate of $10 \%$. In the fruitful consultation made [16], the useful life period for the four variants of technologies analyzed is established, being equal to the 25 years for wet technologies and 35 years for dry technologies, taking a 20year horizon to affect the movement of funds.

\subsection{Initial system balance}

The average unit costs in USD/kW for various condensation technologies were obtained in the consultation made to HOLTEC, these being considered current when acquired directly from the supplier with update date 03/2019. A summary of these costs is provided in Table 5 .

To update equipment costs for periods other than the preparation of this report, you can go to the Marshall \& Swift Equipment Cost Index (M\&S), the most accepted cost index rate among the main suppliers of condensation systems according to the paper [19]. This rate is described by:

$$
V_{M S}=V_{A A} \cdot\left(I_{11} / I_{A A}\right)
$$

where, $V_{A A}$ is the value of available equipment cost, in MUSD; $I_{11}$ is the Marshall index on the date it is intended to assess the cost; $I_{A A}$ is the Marshall index of the date that the equipment cost is available.

Table 5. Cost for different condensation technologies

\begin{tabular}{cc}
\hline Condensation technology & Unit cost (USD/kW) \\
\hline Wet tower & 88.12 \\
Horizontal wet condenser (one pass) & 70.46 \\
ACC (forced throw) & 93.21 \\
Dry tower & 95.56 \\
\hline
\end{tabular}

Table 6 provides the indexes $(M \& S)$ for thermal exchange equipment. Table 7 shows the steam flow to condense in each variant. In the initial basic engineering project presented by the contracting entity [2], an HWC with an outlet vapor pressure of $9 \mathrm{kPa}$ was proposed as a condensation system; however, other alternatives are not contemplated in this project of condensation systems.

The heat flow to be evacuated for each operational situation is detailed in Table 8, while, in the Table 9 are given the water flow required for wet condensers in each variant analyzed. For both powers, the variant considered as critical is variant 1 , as it includes the states of maximum operating requirements, and therefore, the case study will be based on its basis.

Table 6. Indexes Marshall \& Swift Equipment Cost Index

\begin{tabular}{cccc}
\hline Year & Index M\&S & Year & Index M\&S \\
\hline 1920 & 100 & 2005 & 1464.1 \\
1930 & 152.1 & 2010 & 1695.1 \\
1950 & 285.2 & 2012 & 1798.1 \\
1960 & 382.6 & 2014 & 1906.8 \\
1970 & 516.5 & 2016 & 2020.8 \\
1980 & 697.2 & 2017 & 2081.6 \\
1990 & 941.4 & 2019 & 2144.9 \\
2000 & 1262 & 2020 & 2171.6 \\
\hline
\end{tabular}

Table 7. Steam flow to condense in each variant, in $\mathrm{kg} / \mathrm{s}$

\begin{tabular}{ccc}
\hline Variant & BPP 20 MW & BPP 50 MW \\
\hline Variant 1 & 19.1 & 56.1 \\
Variant 2 & 5.8 & 24.5 \\
Variant 3 & 5.7 & 24.1 \\
Variant 4 & 18.7 & 55.0 \\
\hline
\end{tabular}

Table 8. Heat rejected in each variant, in MW

\begin{tabular}{ccc}
\hline Variant & BPP 20 MW & BPP 50 MW \\
\hline Variant 1 & 54.2 & 131.5 \\
Variant 2 & 13.6 & 57.4 \\
Variant 3 & 53.7 & 130.1 \\
Variant 4 & 13.5 & 57.1 \\
\hline
\end{tabular}

Table 9. Water flow required for wet condensers

\begin{tabular}{lcccc}
\hline Variant & \multicolumn{2}{c}{ BPP 20 MW } & \multicolumn{2}{c}{ BPP 50 MW } \\
& HWC & WCT & HWC & WCT \\
\hline Variant 1 & 170.6 & 34.0 & 209.2 & 42.7 \\
Variant 2 & 124.1 & 24.9 & 172.9 & 34.8 \\
Variant 3 & 169.7 & 33.8 & 199.2 & 40.6 \\
Variant 4 & 130.6 & 26.0 & 182.2 & 36.4 \\
\hline
\end{tabular}

\subsection{Analysis of the main results of the case study}

Several selection criteria are used in the evaluation of the four variants of technologies analyzed in this study, these criteria are:

$\begin{array}{ll}1- & \text { Pay off period } \\ 2- & \text { Interest rate of return (IRR) } \\ 3- & \text { Net present value (NPV) } \\ \text { 4- } & \text { Life cycle cost }\end{array}$

1- $\quad$ Pay off period

4- Life cycle cost 


\section{5- $\quad$ Level energy cost}

6- Cost benefit ratio.

Due to the volume of information and variables involved, the results obtained for the BPP of $20 \mathrm{MW}$ and $50 \mathrm{MW}$ are summarized and presented in Tables 10 and 11. Here, load factors and losses equal to 0.72 and 0.58 are taken respectively, an average cost of energy sales of $0.127 \mathrm{USD} / \mathrm{kWh}$, as well as
19.1 equivalent hours of charging, as stipulated by the research [11]. The mitigation costs are equal to the sum of costs of emissions, operational pollution and cooling water consumption. Previously it was given the criteria of several authors in which they establish the levelized cost of energy for ACC between 40 to 80 USD/MW. The results obtained in this work are located in this range [20-23].

Table 10. Summary of the case study for a 20 MW BPP

\begin{tabular}{|c|c|c|c|c|}
\hline Elements & HWC & WCT & $\mathrm{ACC}$ & DCT \\
\hline FOB cost equipment (MUSD) & 1350.9 & 1760.7 & 1909.4 & 1988.8 \\
\hline \multicolumn{5}{|c|}{ Initial Ticket Balance } \\
\hline Active power delivered (MW) & 19.6 & 19.4 & 18.5 & 18.3 \\
\hline Electrical consumption (MWh) & 945.9 & 1037.6 & 1431.7 & 1479.2 \\
\hline Electrical losses (MWh) & 61.3 & 60.6 & 57.8 & 57.2 \\
\hline Total energy sold (GWh) & 71.3 & 70.2 & 65.2 & 64.1 \\
\hline Revenue from energy sales (MUSD) & 2055.5 & 2022.5 & 1879.6 & 1846.5 \\
\hline \multicolumn{5}{|c|}{ Initial balance of outputs } \\
\hline Bagasse consumption $(\mathrm{t} / \mathrm{h})$ & 37.0 & 37.4 & 39.2 & 39.6 \\
\hline $\mathrm{CO}_{2}$ emissions $(\mathrm{t} / \mathrm{h})$ & 11.8 & 12.0 & 12.5 & 12.7 \\
\hline Cost of power not served (MUSD) & 0.0 & 22.0 & 133.1 & 157.3 \\
\hline Maintenance costs (MUSD/year) & 27.0 & 52.8 & 15.3 & 35.8 \\
\hline $\begin{array}{l}\text { Water chemical treatment costs } \\
\text { (MUSD/year) }\end{array}$ & 14.2 & 44.0 & 0.0 & 0.0 \\
\hline Mitigation cost (MUSD/year) & 183.8 & 131 & 175.7 & 183 \\
\hline Partial operating costs (MUSD/year) & 225.0 & 239.5 & 252.7 & 286.5 \\
\hline Linear depreciation (MUSD/year) & $\begin{array}{l}76.7 \\
\text { Utilit }\end{array}$ & 98.8 & 76.2 & 79.2 \\
\hline Utilities (MUSD/year) (with taxes paid) & 1198.3 & 1150.1 & 1058.7 & 1010.2 \\
\hline \multicolumn{5}{|c|}{ Selection criteria for investment alternatives } \\
\hline Pay off Period, $10 \%$ update rate. (years) & 6.2 & 7.5 & 8.4 & 10.3 \\
\hline $\operatorname{IRR}(\%)$ & 28.1 & 20.8 & 18.2 & 15.5 \\
\hline NPV $(15 \%)$ & 2113.9 & 1229.8 & 1126.9 & 121.8 \\
\hline Life cycle cost, (MUSD) & 7547.8 & 10426.8 & 10682.4 & 10957.8 \\
\hline Level energy cost, (USD/kWh) & 0.057 & 0.065 & 0.071 & 0.073 \\
\hline Cost benefit relation & 0.28 & 0.118 & 0.105 & 0.01 \\
\hline
\end{tabular}

Note: In Table 10 and 11, are used the recommendations given by US. Department of Energy for selection of the best investment alternatives.

Table 11. Summary of the case study for a $50 \mathrm{MW}$ BPP

\begin{tabular}{ccccc}
\hline Elements & HWC & WCT & ACC & DCT \\
\hline FOB cost equipment (MUSD) & 2522.9 & 3318.7 & 4255.9 & 4732.1 \\
Active power delivered (MW) & Initial Ticket Balance & & \\
Electrical consumption (MWh) & 48.5 & 47.6 & 46.2 & 45.9 \\
Electrical losses (MWh) & 2077.2 & 2328.2 & 3115.2 & 3173.2 \\
Total energy sold (GWh) & 151.6 & 148.8 & 144.4 & 143.5 \\
Revenue from energy sales (MUSD) & 177.1 & 172.9 & 164.5 & 163.0 \\
& 5100.4 & 4979.4 & 4737.5 & 4693.6 \\
Bagasse consumption (t/h) & Initial balance of outputs & & \\
CO 2 emissions (t/h) & 90.9 & 92.6 & 95.4 & 96.0 \\
Cost of power not served (MUSD) & 29.1 & 29.6 & 30.5 & 30.7 \\
Maintenance costs (MUSD/year) & 0.0 & 31.9 & 131.9 & 139.3 \\
Water chemical treatment costs & 53.3 & 99.9 & 29.8 & 68.0 \\
(MUSD/year) & 28.0 & 76.6 & 0.0 & 0.0 \\
Mitigation cost (MUSD/year) & 323.3 & 240.1 & 370.2 & 380.6 \\
Partial operating costs (MUSD/year) & 404.5 & 448.3 & 532.0 & 574.4 \\
Linear depreciation (MUSD/year) & 142.9 & 177.9 & 160.8 & 170.9 \\
& Utilities & & & \\
Utilities (MUSD/year) (with taxes paid) & 3114.2 & 2976.1 & 2763.7 & 2696.8 \\
Selection criteria for investment alternatives & & \\
Pay off Period, 10\% update rate. (years) & 4.4 & 5.6 & 7.6 & 9.2 \\
IRR (\%) & 41.5 & 31.1 & 23.8 & 19.3 \\
NPV (15\%) & 8034.1 & 5953.3 & 3024.0 & 2026.4 \\
Life cycle cost, (MUSD) & 16283.7 & 21327.9 & 24406.1 & 25407.3 \\
Level energy cost, (USD/kWh) & 0.05 & 0.055 & 0.062 & 0.065 \\
Cost benefit relation & 0.493 & 0.279 & 0.124 & 0.08 \\
\hline
\end{tabular}




\section{CONCLUSIONS}

The analysis of the results obtained in the evaluation process of the operation of an ACC in each study variant confirms that its use is possible. In the case study, the behavior of four variants of condensation technologies in two base powers (20 and $50 \mathrm{MW}$ ) is examined, applying the rapid Kaplan methodology.

In both powers the most critical variant is considered to be the one with the highest volume of heat to be rejected and the highest associated cooling water consumption. Although the case study shows that wet technology has more favorable indicators, its use requires about $160 \mathrm{~m}^{3} / \mathrm{h}$ of water, a value higher than the levels currently available.

The analyses were carried out for a horizon of 20 years, obtaining for the ACC uses, a pay off period of 7.6 and 8.4 years, for the facilities of 20 and $50 \mathrm{MW}$ respectively. With the uses of the selection criteria for investment alternatives, was obtained that for facilities of 20 and $50 \mathrm{MW}$ respectively, the Return Interest Rate (IRR) is 18.2 and 23,8 percent, the Net Present Value (NPV) (with $15 \%$ update rate) is equal to 1126.9 and 3024.0 MUSD, the cost of the life cycle is 10682.4 and 24406.1 MUSD, while, the levelized cost of electricity production is 0.062 and $0.071 \mathrm{USD} / \mathrm{kWh}$, with a cost-benefit ratio of 0.1 and 0.13 . The results obtained confirm the feasibility of using ACC systems

\section{REFERENCES}

[1] Huang, X., Chen, L., Kong, Y., Yang, L., Du, X. (2018). Effects of geometric structures of air deflectors on thermo-flow performances of air-cooled condenser. International Journal of Heat and Mass Transfer, 118: 1020-1032.

https://doi.org/10.1016/j.ijheatmasstransfer.2017.11.071

[2] ECIAZ. (2019). Datos técnicos e ingeniería básica para el proyecto de instalación de BPP de biomasa en el quinquenio 2020-2025, (ECIAZ, SA.), La Habana.

[3] INRH. (2019). Boletín de Análisis de lluvias, embalses, acuíferos y costo del agua, Dirección de Uso Racional del Agua, INRH, La Habana. http://www.inrh.gob.cu/032019.htm, accessed on Nov. 17, 2019.

[4] IDEA. (2019). World Energy Resources 2018, Oklahoma University State, 21-22.

[5] Owen, M., Kröger, D.V. (2017). A numerical investigation of vapor flow in large air-cooled condensers. Applied Thermal Engineering, 127: 157-164. http://dx.doi.org/10.1016/j.applthermaleng.2017.08.026

[6] Huang, X., Chen, L., Kong, Y., Yang, L., Du, X. (2018). Effects of geometric structures of air deflectors on thermo-flow performances of air-cooled condenser. International Journal of Heat and Mass Transfer, 118: 1022-1039.

https://doi.org/10.1016/j.ijheatmasstransfer.2017.11.071

[7] Camaraza, Y. (2017). Introducción a la termo transferencia, Editorial Universitaria, La Habana, 2017.

[8] Da Silva, J.A.M., Ávila Filho, S., Carvalho, M. (2017). Assessment of energy and exergy efficiencies in steam generators. Journal of the Brazilian Society of Mechanical Sciences and Engineering, 39(8): 3217-3226. http://dx.doi.org/10.1007/s40430-016-0704-6

[9] Abdul Malek, A.B.M., Hasanuzzaman, Md., Abd Rahim, N., Al Turki, Y.A. (2017). Techno-economic analysis and environmental impact assessment of a 10 MW biomass-based power plant in Malaysia. Journal of Cleaner Production, 141: 502-513. http://dx.doi.org/10.1016/j.jclepro.2016.09.057

[10] Deng, H., Liu, J., Zheng, W. (2019). Analysis and comparison on condensation performance of core tubes in air-cooling condenser. International Journal of Heat and Mass Transfer, 135: 717-731. https://doi.org/10.1016/j.ijheatmasstransfer.2019.02.011

[11] DNC, Generación eléctrica en Cuba. (2019). Despacho Nacional de Carga, La Habana, Cuba. http://www.dnc.une.cu/generacion2019.htm, accessed on Jan. 12, 2020.

[12] ONEI, Estadísticas energéticas de la revolución, 2019. Oficina Nacional de Estadística, La Habana, Cuba. Available in: http://www.one.cu/aec2019.htm, accessed on Jan. 17, 2020

[13] Camaraza-Medina, Y., Hernández-Guerrero, A., Luviano-Ortiz, J.L., Mortensen-Carlson, K., CruzFonticiella, O.M., García-Morales, O.F. (2019). New model for heat transfer calculation during film condensation inside pipes. International Journal of Heat and Mass Transfer, 128: 344-353. https://doi.org/10.1016/j.ijheatmasstransfer.2018.09.012

[14] HOLTEC INTERNATIONAL. (2019). Budgetary proposal for PhD. Yanán Camaraza, Universidad Central de Las Villas, Cuba.

[15] Camaraza-Medina, Y., Hernandez-Guerrero, A., Luviano-Ortiz, J.L., Cruz-Fonticiella, O.M., GarcíaMorales, O.F. (2019). Mathematical deduction of a new model for calculation of heat transfer by condensation inside pipes. International Journal of Heat and Mass Transfer, 141: 180-190. https://doi.org/10.1016/j.ijheatmasstransfer.2019.06.0 76

[16] Department of Energy (DOE). (2018). A rapid guide to perform Life Cycle Cost, Washington.

[17] Xiao, L., Ge, Z., Kong, X., Yang, L., Du, X. (2018). Numerical study on performance improvement of aircooled condenser by water sprays cooling. International Journal of Heat and Mass Transfer, 125: 1028-1042. https://doi.org/10.1016/j.ijheatmasstransfer.2018.05.006

[18] Zhan, F., Zhuang, D., Ding, G., Ju, P., Tang, J. (2018). Influence of wet-particle deposition on air-side heat transfer and pressure drop of fin-and-tube heat exchanger. International Journal of Heat and Mass Transfer, 124: 1230-1244. https://doi.org/10.1016/j.ijheatmasstransfer.2018.04.049

[19] Camaraza-Medina, Y., Cruz-Fonticiella, O.M., García-Morales, O.F. (2019). New model for heat transfer calculation during fluid flow in single phase inside pipes. Thermal Science and Engineering Progress, 11: 162-166. https://doi.org/10.1016/j.tsep.2019.03.014

[20] Chen, L., Yang, L., Du, X., Yang, Y. (2018). Novel aircooled condenser with $\mathrm{V}$-frame cells and induced axial flow fans. International Journal of Heat and Mass Transfer, 117: 167-182. https://doi.org/10.1016/j.ijheatmasstransfer.2017.09.139

[21] Camaraza-Medina, Y., Hernández-Guerrero, A., Luviano-Ortiz, J.L, Cruz-Fonticiella, O.M., GarcíaMorales, O.F. (2019). Empleo de condensadores secos en centrales termoeléctricas de biomasa: un caso de estudio. Centro Azúcar, 46(2): 21-34. 
[22] Sagastume-Gutiérrez, A., Cabello-Eras, J.J., Hens, L., Vandecasteele, C. (2018). Data supporting the assessment of biomass based electricity and reduced GHG emissions in Cuba. Data in Brief, 17: 716-723. https://doi.org/10.1016/j.dib.2018.01.071
[23] Rye, C.D., Jackson, T. (2018). A review of EROEIdynamics energy-transition models. Energy Policy, 122:

https://doi.org/10.1016/j.enpol.2018.06.041 